\title{
Galbanum Oil
}

National Cancer Institute

\section{Source}

National Cancer Institute. Galbanum Oil. NCI Thesaurus. Code C72188.

The oily resin extracted from Ferula galbaniflua. Galbanum oil is used primarily in aromatherapy. 